\title{
BODY WEIGHT PERCEPTION AND ASSOCIATED FACTORS IN STUDENTS
}

\author{
Fernanda Nascimento Pereira ${ }^{1}$, Jéssica Rodrigues de Oliveira ${ }^{1}$, Cristina Carpentieri Zöllner ${ }^{2}$, \\ Ana Maria Dianezi Gambardella ${ }^{1}$
}

\begin{abstract}
Objective: analyze the association between body weight perception and related variables in Elementary School students. Methods: cross-sectional study performed in 2007 with students aged 8 to 17, residents of Vitoria (ES). Anthropometric, demographic, socioeconomic and sexual maturation data were collected. Body weight perception was established by one single question of what the students thought of their own body weight in relation to their height. Logistic regression analysis stratified by gender was used to verify the associations among body weight perception and age, body mass index, waist circumference, pubertal stage and socioeconomic status. The reference category for analysis was "adequate weight perception". Results: three hundred and ninety-seven students participated in the study, 52.4\% were females, and the age average (standard deviation) was 12 (1.84) years. Nutritional status for boys and girls showed, respectively, $21.7 \%$ and $20.1 \%$ overweight, $76.9 \%$ and $77.8 \%$ normal weight for height, $1.4 \%$ and $2.1 \%$ underweight. There was statistic association between body weight perception and nutritional status (overweight) for both genders (boys: $O R=6.76$, girls: $O R=19.58$ ), and age $(10$ to 14 years) for boys $(O R=0.40)$. The other variables did not show any association. Conclusion: body weight perception was associated with nutritional status in both genders, and with age only for boys. This reinforces the need of health professionals to monitor these adolescents in order for them to have a better understanding of their own bodies.
\end{abstract}

Key words: adolescents, nutritional status, body image, body weight.

\section{INTRODUCTION}

Everything that an individual notices about his/her body contributes to the shaping of their own body image, which can be defined as the figurative representation of what the individual mentally conceives in relation to the size, shape and structure of the body ${ }^{1,2}$.

However, the image is not formed based only on what the body notices separately, but also by how each individual's personality interprets the sensations and experiences lived by the body, that is, how the individual deals with everything that is related to the physical appearance ${ }^{1,3}$. Such phenomenon is structured according to the constant changes that occur in the external world of each individual and among the social relationships ${ }^{1,2}$.

The identity formation and constant body changes make the adolescent group vulnerable to social and cultural changes. They tend to present concerns regarding their body weight because they long for a slender body, and for fear of being excluded from the group to which they belong ${ }^{4}$.

The cult of slenderness is somewhat paradoxical in our society, since we are exposed, by the media, to a high energy density food supply derived from fats and sugars. And, the same media leads us to cultivate a lean body, contributing to the prejudice against obesity and unhealthy eating habits ${ }^{5}$. For the teens, it becomes more and more difficult to consider beauty as an individual and singular characteristic when they are facing the display of ultra thin or muscular bodies on the cover of magazines and commercial advertisement via television, internet etc. ${ }^{6,33}$.

The media influence on the individual, and on the world the adolescents belong to can be indirect or direct, in such a way that the body

1 Faculdade de Saúde Pública, Universidade de São Paulo. Avenida Doutor Arnaldo, 715, Cerqueira César, São Paulo / SP, $01246-904$.

2 Secretaria Estadual de Saúde do Espírito Santo. Av. Marechal Mascarenhas de Moraes, 2025 - Bento Ferreira, Vitória/ES, $29050-625$. Departamento de Nutrição, Faculdade de Saúde Pública, Universidade de São Paulo.

Based on the Masters Dissertation: "Body weight perception and associated factors in Elementary School students in Vitória (ES)". Corresponding Author: fenasper@usp.br

Suggested citation: Pereira FN et al. Body weight perception and associated factors in students. Journal of Human Growth and Development 2013, 23(3): 296-302

Manuscript submitted Feb 13 2013, accepted for publication Jul 202013. 
standard described by the media refers to the unreal standard, pointing itself attractive for the adolescent's comparison with him/herself ${ }^{7}$. Besides, the parents are no longer the source for information, a role now assigned to what their peers and the society consider "rules" to be followed ${ }^{7}$.

When we study body image according to sex, we observe that boys and girls deal with their own body transformations in different ways. Furthermore, the identity built until then for a childlike body begins to be reconstructed for a body undergoing rapid transformations, and for the girls with the arrival of menstruation and the development of secondary sexual characteristics, this becomes more pronounced 8 .

For boys, their own built body image is composed from elements that refer to the appreciation of muscular bodies as a reference for the ideal male model. While girls are stimulated to lose weight to meet the beauty standard demands, the boys are stimulated to increase their muscles to reinforce their masculinity. Therefore, it can be said that individuals build their body image from experiences that are representative of each gender's universe ${ }^{9,10}$.

All these body transformations, added to the specific social and cultural ideals for each sex, may offer the adolescent a feeling of frustration before what he/she desires ${ }^{11}$. The effect of changes during the beginning of puberty also causes a contrast in the emotional development according to sex, that is, the girls tend to have less self-assurance than the boys because girls are seen as more or less attractive by their peers ${ }^{11}$.

Considering that it is important to know and better comprehend the factors related to body weight perception in adolescents, information on body image perception in adolescents from the city of Vitória, capital of the state of Espírito Santo (ES), will be provided in order to contribute to a better understanding of this subject. Thus, the objective of this study was to analyze the association between body weight perception and related variables in students aged 8 to 17 years.

\section{METHODS}

Data are from the cross-sectional study performed in $2007^{12}$ with students from fourth to ninth grade of the Brazilian Elementary School System, enrolled in public and private schools in the city of Vitória, capital of Espírito Santo (Brazil).

The sample was planned according to the total of 14,734 students. In the first stage, 12 public and 6 private schools were randomly selected from a pool of 42 schools in the city, considering the proportionality of its distribution. Then, the schools were drawn according to the administrative regions: Continental, Maruípe and Bento Ferreira / Jucutuquara, selected by the Department of Education of Vitória, because they were at easy access locations, in order to ensure the sample representativeness for these regions.

After the schools were established, a systematic random sampling was performed among the enrolled students for the selection of those who would be studied. The predicted initial sample was of 450 individuals, considering 25 students per school. The sample size calculation considered the student population from the grades of interest in the 3 administrative regions with a $5 \%$ margin of error.

Data were collected from 404 individuals, three girls were excluded ( 2 reported the possibility o pregnancy and 1 was mentally disabled) along with four boys that provided incomplete dada.

Nutrition undergraduate students, trained and supervised by nutritionists, collected the data by interviewing the participants and gathering their anthropometric measurements at the students' schools. Data were registered in a previously tested questionnaire. Another questionnaire, along with a consent form were sent to the parents for collecting family data.

Body weight perception was verified by asking the students one single question about how they perceived their weight in relation to their height (extremely low, low, adequate, high, extremely high). For data analysis, we chose to rearrange the categories into "adequate" (considering the answer "adequate") as the reference point, and "inadequate" (considering the remaining answers). Students' body mass index (BMI) was calculated $\left(\right.$ BMI $=$ weight $/$ height $^{2}$ ) from students' measurements obtained of body weight (in kilograms) and height (in centimeters), according to the techniques described by GORDON et al. ${ }^{13}$. All measurements were performed in duplicates and the mean value was used for the analysis.

Body weight was measured on a Tanita ${ }^{\circledR}$ microelectronic portable digital scale, which has a $150 \mathrm{~kg}$ capacity and a 0,1 kg resolution. And height was measured using an Alturaexata ${ }^{\circledR}$ vertical stadiometer with a $0,1 \mathrm{~cm}$ resolution.

Students' nutritional status was verified according to the BMI classification proposed by COLE et al. ${ }^{14,15}$. These classification present critical values for classifying individuals 2 to 18 years of age as underweight, at risk of obesity and as obese, according to sex, and used population data from 6 countries, including Brazil. For the regression analysis we created the category "adequate weightfor-height" which was used as reference.

Waist circumference was measured according to the techniques described by CALLAWAY et al. ${ }^{16}$. The measurements were registered in centimeters, in duplicates and the numbers were not rounded. We considered the 90th percentile of the waist circumference percentile curve proposed by MCCARTHY et al. ${ }^{17}$, for the students aged 8 to 17 years, according to sex and age bracket, which classifies the individuals with fat accumulation around the waist area. Those classified under the 
90th percentile of the waist circumference were used as reference for the regression analysis.

The assessment of sexual maturity stage was performed by a self-evaluation of the secondary sex characteristics, based on the comparison of photos of the 5 sexual maturity stages that characterize the sexual development of children and adolescents, according to criteria proposed by TANNER ${ }^{18}$. For males we considered the development of the genitals (G1, G2, G3, G4 and G5) and for females the development of breasts (B1, B2, B3, B4 and B5) evaluated according to size, shape and characteristics. The development of pubic hair (P1, P2, P3, P4 e P5) was evaluated for both sexes according to amount, distribution and characteristics. A brief explanation was given to the students regarding the different stages and also how the questionnaire should be filled out.

Age was obtained from the difference between the dates of the interviews and of birth of each individual, in years, and divided into categories: 8 to 10,10 to 14 and 14 to 18 years. Such categories are related to the individual biological development, and the age bracket 8 to 10 was used as the reference category for the regression analysis. As a social and cultural variable we used maternal education, classified in years: $<8$ years and $>8$ years. Gender was classified as female and male.

We performed logistic regression analysis to determine the effect of independent variables (nutritional status, age and waist circumference) for the student's body weight perception using the category "adequate weight" as reference. Variable selection and verification of entry order in the final model was performed by univariate analysis, considering significance level of $p<0.20$. Analyses stratified by sex were held to verify possible behavior differences of variables among boys and girls. All analyzes were adjusted by maternal education and sexual maturity stage.

Statistical calculations were performed using Stata 10.1 (Stata Corporation, College Station, TX 2007), considering a significance level of 0.05 .

The Ethics Research Committee of the Faculdade de Saúde Pública da Universidade de São Paulo approved this survey. Parents or legal guardians of the students signed a consent form allowing their participation in the research. Students classified as underweight or overweight (risk for obesity or obesity) were sent to the public health service of the city of Vitória (ES) for a follow up with professionals.

\section{RESULTS}

Three hundred and ninety-seven students participated in this study, age average (standard deviation) was of 12 years (1.84) and $52.4 \%$ were females. Boys and girls were assessed as overweight $21.7 \%$ and $20.1 \%$, as normal weight for height $76.9 \%$ and $77.8 \%$, and as underweight $1.4 \%$ e $2.1 \%$, respectively.

For girls, weight, BMI, and WC presented statistically significant association with body perception, whose means were higher among those who perceived their body weight as inadequate (above the adequate weight). The same was observed for boys, especially for height (Table 1 ).

Table 1: Distribution of students aged 8 to 17 years, and mean (SD) height, weight, body mass index (BMI), and waist circumference (WC), according to sex and body perception, Vitória (ES), Brazil, 2007

\begin{tabular}{|c|c|c|c|c|c|c|c|c|}
\hline \multirow{2}{*}{$\begin{array}{c}\text { Body } \\
\text { image } \\
\text { perception }\end{array}$} & \multicolumn{2}{|c|}{ Stature $(\mathrm{cm})$} & \multicolumn{2}{|c|}{ Weight (kg) } & \multicolumn{2}{|c|}{ BMI $(\mathrm{kg} / \mathrm{m} 2)$} & \multicolumn{2}{|c|}{ WC $(\mathrm{cm})$} \\
\hline & & & & & & & & \\
\hline \multirow{2}{*}{ Low } & 147,5 & 145,2 & 35,3 & 36,6 & 15,9 & 17,1 & 57,7 & 60,9 \\
\hline & $(10.83)$ & (13.65) & $(8.37)$ & $(10,39)$ & $(1,85)$ & $(2,16)$ & $(4,63)$ & $(5,74)$ \\
\hline \multirow{2}{*}{ Adequate } & 150,9 & 152,3 & 40,9 & 43,5 & 17,7 & 18,4 & 61,2 & 64,8 \\
\hline & $(10,43)$ & $(13,14)$ & $(9,03)$ & $(12,03)$ & $(2,24)$ & $(2,57)$ & $(5,12)$ & $(5,96)$ \\
\hline \multirow{2}{*}{ High } & 153,3 & 153,2 & 52,5 & 53,9 & 22,2 & 22,4 & 70,7 & 73,1 \\
\hline & $(8.37)$ & $(13,62)$ & $(11,10)$ & $(18,48)$ & $(3,69)$ & $(4,57)$ & $(7,46)$ & $(10,68)$ \\
\hline
\end{tabular}

Notes:

1 Body weight perception in relation to height

$* \mathrm{p}<0.001, * * \mathrm{p}<0.05, * * * \mathrm{p}>0.05$ (values of $\mathrm{p}$ in relation to the categories low, adequate, and high)

We observed in boys, a statistically significant difference between body perception and nutritional status, and in girls only in nutritional status. There was a higher prevalence among boys who perceived their weight as adequate but were overweight, than in girls with the same perception and nutritional status. About half of the students from both genders perceived their weight as inadequate (extremely high, high, extremely low or low) when the nutritional status showed normal weight. There was statistically significant association between waist circumference and body perception only among girls. The remaining variables did not present statistically significant association with body perception (Table 2). 
Table 2: Distribution of students of both sexes, aged 8 to 17 years, according to body perception and independent variables, Vitória (ES), Brazil, 2007

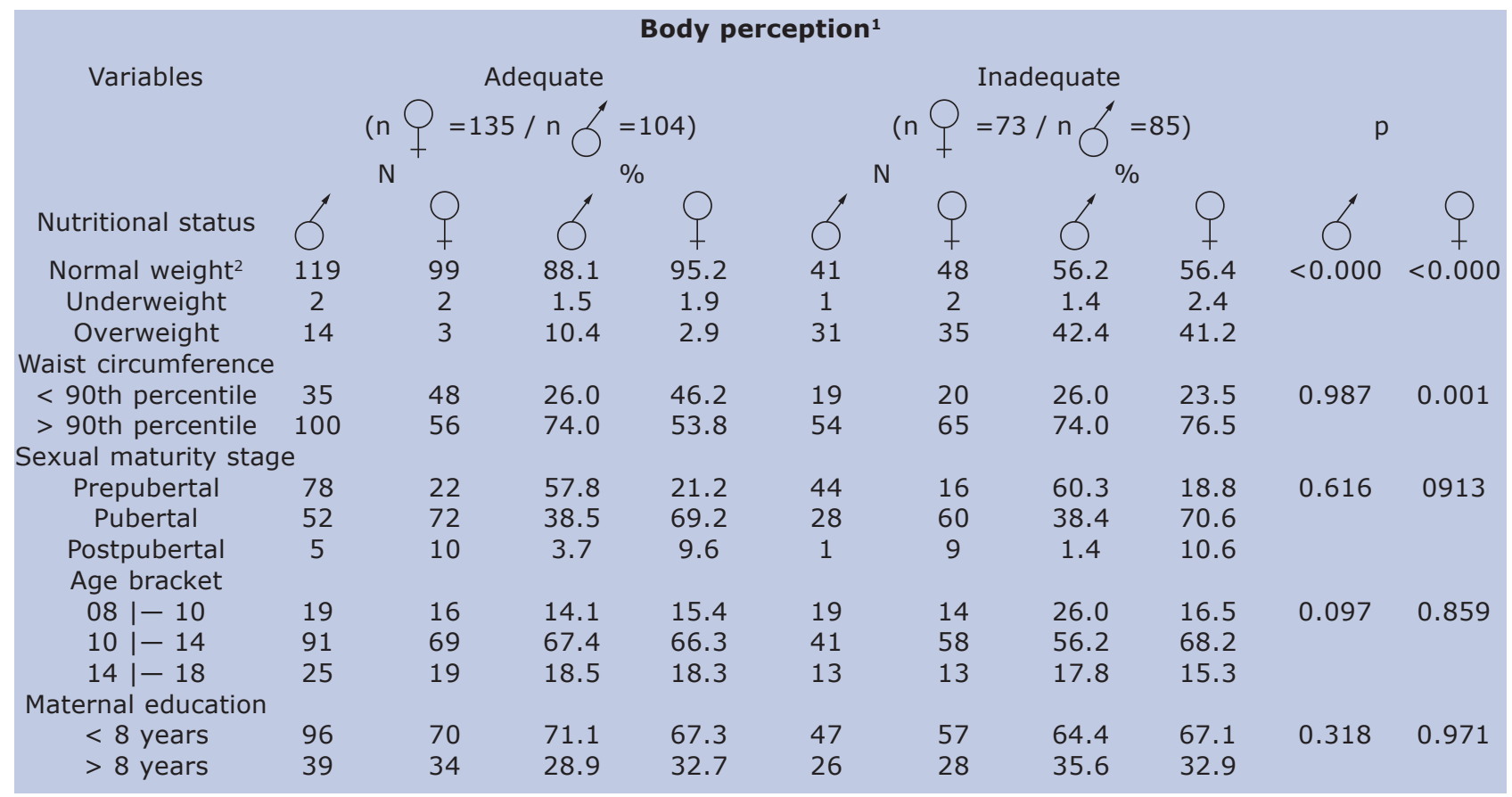

Notes:

1 Body weight perception in relation to height

2 Normal weight for height

Association between body perception and the variables nutritional status and age bracket was observed in boys. Overweight individuals presented a 6.76 OR in relation to perceiving their own body weight as inadequate, for those aged 10 to 14 , the OR was 0.40 in relation to the same perception, when compared with the other age brackets (Table 3 ).

Table 3: Association between body perception and nutritional status, age bracket and waist circumference, in boys, Vitória (ES), Brazil, 2007

\begin{tabular}{|c|c|c|c|c|}
\hline Variables & Crude OR (IC 95\%) & $\mathbf{p}$ & Adjusted OR 1 (IC 95\%) & $\mathbf{p}$ \\
\hline \multicolumn{5}{|l|}{ Nutritional Status } \\
\hline Normal weight for height & 1.00 & - & 1.00 & - \\
\hline Underweight & $2.90(0.40-21.27)$ & 0.294 & $2.31(0.29-17.98)$ & 0.425 \\
\hline Overweight & $6.43(3.12-13.26)$ & $<0.001$ & $6,76(3.00-15.22)$ & $<0.001$ \\
\hline \multicolumn{5}{|l|}{ Age (years) } \\
\hline $08 \mid-10$ & 1.00 & - & 1.00 & - \\
\hline $10 \mid-14$ & $0.45(0.22-0.94)$ & 0.034 & $0.40(0.18-0.93)$ & 0.033 \\
\hline $14 \mid-18$ & $0.56(0.22-1.40)$ & 0.213 & $0.58(0.19-1.75)$ & 0.333 \\
\hline \multicolumn{5}{|l|}{ Waist circumference $(\mathrm{cm})$} \\
\hline$>90^{\text {th }}$ percentile & 1.00 & - & - & - \\
\hline$>90^{\text {th }}$ percentile & $0.95(0.50-1.80)$ & 0.863 & - & - \\
\hline
\end{tabular}

Note:

1 Adjusted by the variables sexual maturity stage and maternal education

OR: odds ratio

The OR was 19.58 for girls who perceived their weight as inadequate when their BMI showed they were overweight. The waist circumference did not show any association with body image perception when adjusted (Table 4).

\section{DISCUSSION}

The choice of the most coherent instrument for studying body perception depends on what you want to investigate, since via this instrument you 
Table 4: Association between body perception and nutritional status, age bracket and waist circumference, in girls, Vitória (ES), Brazil, 2007

\begin{tabular}{|c|c|c|c|c|}
\hline Variables & Crude OR (IC 95\%) & $\mathbf{p}$ & Adjusted OR 1 (IC 95\%) & $\mathbf{p}$ \\
\hline \multicolumn{5}{|l|}{ Nutritional Status } \\
\hline Normal weight for height & 1.00 & - & 1.00 & - \\
\hline Underweight & $2.06(0.28-15.09)$ & 0.476 & $2.10(0.27-16.26)$ & 0.476 \\
\hline Overweight & $24.06(7.04-82.19)$ & $<0.001$ & $19,58(5.39-71.12)$ & $<0.001$ \\
\hline \multicolumn{5}{|l|}{ Age (years) } \\
\hline $08 \mid-10$ & 1.00 & - & - & - \\
\hline $10 \mid-14$ & $0.96(0.43-2.13)$ & 0.921 & - & - \\
\hline $14 \mid-18$ & $0.78(0.29-2.14)$ & 0.632 & - & - \\
\hline \multicolumn{5}{|l|}{ Waist circumference $(\mathrm{cm})$} \\
\hline$<90^{\text {th }}$ percentile & 1.00 & - & 1.00 & - \\
\hline$>90^{\text {th }}$ percentile & $2.79(1.48-5.24)$ & 0.001 & $1.36(0.61-3.06)$ & 0.452 \\
\hline
\end{tabular}

Note:

1 Adjusted by the variables sexual maturity stage and maternal education

OR: odds ratio

can verify both how well the individual sizes his/ her body, and also the cognitive and behavioral aspects the individual presents, while providing better understanding of the given results ${ }^{19}$. The most used instruments in epidemiological research, and in clinical practice, are questionnaires, group or single interviews, and forms with body silhouette scales, that aim to identify discrepancies between the real and the desired body, and the feelings, emotions, behaviors and attitudes related 20,32 . The instrument used in the present study allowed us to verify body weight perception in a simple, practical and cheap way, when compared with instruments used in other studies that can be used in population studies and in clinical practices with adolescents.

The prevalence of overweight in both sexes was similar to that of other studies on body weight perception with students of the same age group 21,22 . In the present study, we verified that the nutritional status classified by the BMI as overweight, is associated to the inadequate body weight perception (extremely high, high, extremely low or low) in boys and girls. However, individuals with normal weight for height can also perceive themselves as over or underweight, and this can vary according to the gender $22,23,24$, with a tendency of boys perceiving a lower body weight and girls a higher body weight. This reflects the slender body stereotype for girls and the muscular body for boys, valued nowadays by the western society, in addition to the pressure exerted by their social relations, in order for the adolescents to be accepted by their peers and parents ${ }^{24}$.

The high BMI value can reflect changes in body composition that are features of puberty and of each gender related, for example, to the increase of lean body mass or fat tissue. Many studies on body awareness observed that the prevalence of distortions in body perception was high even among those with adequate nutritional status, what suggests that the weight perceived can be a beauty or a health related concern. It is important to emphasize that the body weight perception as "high" or "low" when related to height, consisted of one category (inadequate), and did not allow a more detailed analysis.

It was expected that the variable waist circumference, a sensitive and specific measure of abdominal body fat in children and adolescents of different ages, would present association with body weight perception, because the body can also be perceived from specific areas such as thighs, waist, buttocks, hips etc. ${ }^{25,26}$. It is important to consider that the classification criteria used as reference contemplates a population of British individuals, whose body shape patterns differ from Brazilian individuals. Studies relating to body perception and other variables that indicate nutritional status are scarce in the scientific literature.

The classification of sexual maturity, through self-evaluation of the secondary characteristics consists in a practical, cheap method, easy to fill out, and that does not depend on the researcher. However, it may result in errors from the examined individuals, and that, in many studies, are impractical to be verified. Aiming to minimize errors, the students received explanations on the differences among the stages, in addition to instructions on how to fill out the form.

Although, we did not observe any association between body perception and sex maturity stage, it may influence body weight perception differently between the genders, due to the physiological changes that occur. Along with the beginning of pubertal development, girls tend to have an increase in fat tissue (without necessarily putting on weight), and considering beauty, social and cultural reasons, they may perceive themselves, in the post pubertal phase, with a body that goes against what is expected for the current beauty standards. The same pattern does not occur in boys, because as they mature sexually their bodies become more like what the male ideal is, due to the increase of muscle 
mass. Therefore, boys may perceive themselves as "thin" and girls as "fat", even when their weight is normal for their height 27,28 . ABBOTT et al. ${ }^{29}$, in an Australian survey with adolescents with the same age groups, found adequate body weight perception of boys that matured before their mates, reinforcing the ideal of manhood, while overweight girls reported some type of concern related to body mass during adolescence.

Maybe, the sexual maturity stage might explain the results found for the variable age, associated to body perception only in boys aged 10 to 14 years. This age group corresponds to the pubertal stage of sexual maturation where the adolescents show an increase in muscular mass due to physiological development and as already discussed, may not notice they are overweight or underweight. Unlike girls, whose concerns with beauty start since early age usually influenced by family members. With time, influenced by the media and their own group, girls tend to be under more pressure to have a slim body. JONES ${ }^{30}$ highlights the importance given to appearance during adolescence, and that aging may provide changes in body weight perception.

The studies that relate body weight perception and social and economic levels are inconclusive. TRICHES et al. ${ }^{31}$ observed that children of mothers with low education levels were more susceptible to perceive their body weight as

\section{REFERENCES}

1. Schilder P. A imagem do corpo. São Paulo: Martins Fontes, 1980.

2. Slade PD. What is body image? Behav Res Ther. 1994, 32(5): 497-502.

3. Cash TF, Jakatdar TA, Williams EF. The body image quality of life inventory: further validation with college men and women. Body Image. 2004, 1: 279-87.

4. Zametkin AJ, Zoon CK, Klein HW, Munson S. Psychiatric aspects of child and adolescent obesity: a review of the past 10 years. J Am Acad Child Adolesc Psychiatry. 2004, 43 (2): 134-50.

5. Andrade A, Bosi MLM. Mídia e subjetividade: impacto no comportamento alimentar feminino. Rev Nutr. 2003, 16 (1): 117-25.

6. Saikali CJ, Soubhia CS, Scalfaro BM, Cordás TA. Imagem corporal nos transtornos alimentares. Rev Psiq Clin. 2004, 31 (4): 164-6.

7. Wiseman CV, Sunday SR, Becker AE. Impact of the media on adolescent body image. Child Adolesc Psychiatr Clin N Am. 2005, 14(3): 453-71.

8. Aberastury A. Adolescência. Porto Alegre: ARTMED, 1990.

9. Smolak L. Body image in children and adolescents: where do we go from here? Body Image. 2004, 1 (1): 15-28. inadequate. The hypothesis presented by these authors was that these adolescents are more vulnerable to social and cultural influences, in addition to expressing greater need to be accepted by the social environment they live in. According to the authors, having a body that meets the preestablished stereotype may represent the false idea of better social status and a possible social mobility. Such argument may be questioned, because if we consider our society as globalized, it would be unlikely to think that poor adolescents would not be influenced in their choices, attitudes, behaviors and thoughts the same way as the rich ones.

The main results of the present study indicate that body weight is perceived in different ways between genders. Overweight students presented inadequate perception, and only in boys we observed association between body weight perception and age group from 10 to 14 years. It is important to emphasize that more studies with the intention of evaluating body weight perception and associated factors, especially in adolescents, are necessary in Brazil. Most studies are cross-sectional studies and therefore it would be of interest to better understand how the body is perceived, and what the influences in this process are during growth and development. This would be accomplished using qualitative and quantitative approaches helping health professionals to better understand the topic and provide better quality of life to the adolescents.

10. Muris P, Meesters C, van de Blom W, Mayer B. Biological, psychological, and sociocultural correlates of body change strategies and eating problems in adolescent boys and girls. Eat Behav. 2005, 6(1): 11-22.

11. McCabe MP, Ricciardelli LA, Banfield S. Body image strategies to change muscles and weight, and puberty: do they impact on positive and negative affect among adolescent boys and girls? Eat Behav. 2001, 2 (2): 129-49.

12. Salvador CCZ. Fatores associados ao estado nutricional dos estudantes da $4^{a}$ a $9^{a}$ série do ensino fundamental de 3 regiões administrativas do município de Vitória [tese de doutorado]. São Paulo: Faculdade de Saúde Pública da USP, 2008.

13. Gordon CC, Chumlea WC, Roche AF, Stature, recumbent length, and weight. In: Lohman TG, Roche AF, Martorrel R. Anthropometric standardization reference manual. Illinois: Human Kinetics Books, 1988. p. 3-8.

14. Cole TJ, Bellizzi MC, Flegal KM, Dietz WH. Establishing a standard definition for child overweight and obesity worldwide: international survey. BMJ. 2000, 320: 240-3.

15. Cole TJ, Flegal KM, Nicholls D, Jackson AA. Body mass index cut offs to define thinness in children and adolescents: international survey. BMJ. 2007,335:194-7. 
16. Callaway CW, Chumlea WC, Bouchard C, Himes $\mathrm{JH}$, Lohman TG, Martin AD et al. Circumferences. In: Lohman TG, Roche AF, Martorrel R. Anthropometric standardization reference manual. Illinois: Human Kinetics Books, 1988. p. 39-54.

17. McCarthy HD, Jarrett KV, Crawley HF. The development of waist circumference percentiles in British children aged $5.0 \pm 16.9$ y. Eur J Clin Nutr. 2001, 55: 902-7.

18. Tanner JM. Growth at adolescence. Oxford: Blackwell Scientific Publications, 1962.

19. Thompson JK. The (mis)measurement of body image: ten strategies to improve assessment for applied and research purposes. Body Image. 2004, 1 (1): 7-14.

20. Banfield SS, McCabe MP. An evaluation of the construct of body image. Adolescence. 2002, 37 (146): 373-93.

21. Araújo CL, Dumith SC, Menezes AMB, Hallal PC. Peso medido, peso percebido e fatores associados em adolescentes. Rev Panam Salud Publica. 2010,27(5):360-7.

22. Castro IRR de, Levy RB, Cardoso LO, Passos MD dos, Sardinha LMV, Tavares LF, et al. Imagem corporal, estado nutricional e comportamento com relação ao peso entre adolescentes brasileiros. Ciênc Saúde Colet. 2010,15 Suppl 2:3099-4108.

23. O'Dea JA, Caputi P. Association between socioeconomic status, weight, age and gender, and the body image and weight control practices of 6 to 19 year old children and adolescent. Health Educ Res. 2001,16 (5): 521-32.
24. Pinheiro AP, Giugliani ERJ. Who are the children with adequate weight who feel fat? J Pediatr. 2006, 82 (3): 232-5.

25. Conti MA, Frutuoso MFP, Gambardella AMD. Excesso de peso e insatisfação corporal em adolescentes. Rev Nutr. 2005,18(4):491-7.

26. Bergström E, Stenlund $H$, Svedjehäll B. Assessment of body perception among Swedish adolescents and young adults. J Adolesc Health, 2000, 26 (1): 70-5.

27. Thompson AM, Chad KE. The relationship of pubertal status to body image, social physique anxiety, preoccupation with weight and nutritional status in young females. Can J Public Health. 2000, 91 (3): 207-11.

28. Labre MP. Adolescent boys and the muscular male body ideal. J Adolesc Health. 2002, 30 (4): 233-42.

29. Abbott BD, Barber BL. Embodied image: gender differences in functional and aesthetic body image among Australian adolescents. Body Image. 2010, 7: 22-31.

30. Jones DC. Body image among adolescent girls and boys: a longitudinal study. Dev Psychol. 2004, 40 (5): 823-35.

31. Triches RM, Giugliani ERJ. Insatisfação corporal em escolares de dois municípios da região Sul do Brasil. Rev Nutr. 2007, 20 (2): 119-28.

32. Conti MA. Os aspectos que compõem o conceito de imagem corporal pela ótica do adolescente. J Hum Growth Dev 2008,18(3):240-53.

33. Marcuzzo M, Pich S, Dittrich MG. A construção da imagem corporal de sujeitos obesos e sua relação com os imperativos contemporâneos de embelezamento corporal. Interface. 2012, 16(43): 943-54. 